Ann. Biol. anim. Bioch. Biophys., 1978, 18 (6), 1363-1369.

\title{
A critical analysis of fasting metabolism data in R. I. R. hens (Gallus gallus)
}

\author{
par R. GEERS, H. MICHELS *, E. DECUYPERE ** \\ Laboratorium voor Eco-Fysiologie der Huisdieren, Fakulteif der Landbouwwetenschappen, \\ Katholieke Universiteit te Leuven, Kardinaal Mercierlaan 92, B - 3030 Heverlee, Belgium.
}

Summary. A total of 19 fasting RIR hens were used in three series of experiments to investigate metabolic parameters $\left(\mathrm{CO}_{2}\right.$ production in $\mathrm{l} / \mathrm{h}$, oxygen consumption in $\mathrm{l} / \mathrm{h}$, heat production in $\mathrm{kJ} / \mathrm{h}$ ) and respiratory quotients $(R Q)$ in relation to body size $(\mathrm{kg})$ and age at different environmental temperatures and fasting durations. No constant interindividual relationships between metabolic parameters and body weight were found. Metabolic parameters increased with decreasing environmental temperatures $\left(25\right.$ to $\left.5{ }^{\circ} \mathrm{C}\right)$, as shown by negative linear relationships. These types of relationships were found between the metabolic parameter magnitudes and fasting durations at $20^{\circ} \mathrm{C}$ in hens more than 1 year old, whereas increasing RQ values were observed with prolonged duration of fasting. No $R Q$ values below 0.7 were found.

\section{Introduction.}

The aim of this report was to investigate the fasting metabolism parameters of laying RIR hens (Gallus gallus) in relation to body size, age, different postnatal environmental temperatures and fasting durations.

According to Kleiber (1965) basal metabolic rate can be expressed as a function of metabolic body weight $\left(B M R=a W^{0.75}\right)$ for interspecies comparison. To adjust fasting metabolic rate for intra-species comparison Thonney ef al. (1976) proposed body weight as a covariable in a statistical model.

We also wished to study $R Q$ values of fasting hens kept in different environmental conditions. According to Romijn and Lokhorst (1961), RQ-values as low as 0.52 were found, although a minimum RQ of 0.707 was assumed on a theoretical physiological basis (King, 1957). Taking into account the importance of this discrepancy for fundamental and applied research on energy metabolism in the domestic fowl and in other birds, we wanted to compare data resulting from our measuring methods (Geers et al., 1978) with those of other authors working in the same field.

* Correspondence to Prof. Dr. H. Michels.

** Supported by the NFWO (Nationaal Fonds voor Wetenschappelijk Onderzoek, België). 


\section{Materials and methods.}

During the years 1974 and 1975, 6 groups of 120 eggs were subjected to different environmental temperatures in force-draught incubators (Michels et al., 1974). The eggs were taken from a pure-bred flock of nearly 1-year old RIR pullets (Gallus gallus) raised at the University Breeding Centre for Laboratory Animals.

From hatching on chickens were kept in a well-ventilated $\left(5,000 \mathrm{~m}^{3} / \mathrm{h}\right)$, airconditioned animal house at a temperature of $25^{\circ} \mathrm{C} \pm 1{ }^{\circ} \mathrm{C}$. Infra-red lamps were used up to 7 days. Vapour pressure was mainfained at $1.6 \mathrm{kPa}(12 \mathrm{~mm} \mathrm{Hg})$. Internal air circulation (air velocity) varied between 10 and $20 \mathrm{~cm} / \mathrm{s}$; light was given at an intensity of about 75 lux from 7 a. m. to 9 p. m. in 1974, from 8 a. m. to 8 p. m. in 1975.

Animals of all ages were fed a commercial diet* and provided with water ad libifum. No prophylactic trealment was given. When the hens were 7 weeks old, 6 were chosen at random from each incubation group and put into individual cages with no visual contact between them. Six months after the onset of incubation, one animal was chosen at random from each incubation treatment for a 1-week metabolic experiment (table 1).

\section{TABLE 1}

Chronological order in a metabolic experiment

(Exp. I and II : 7 days ; Exp. III : 10 days) for eoch animal

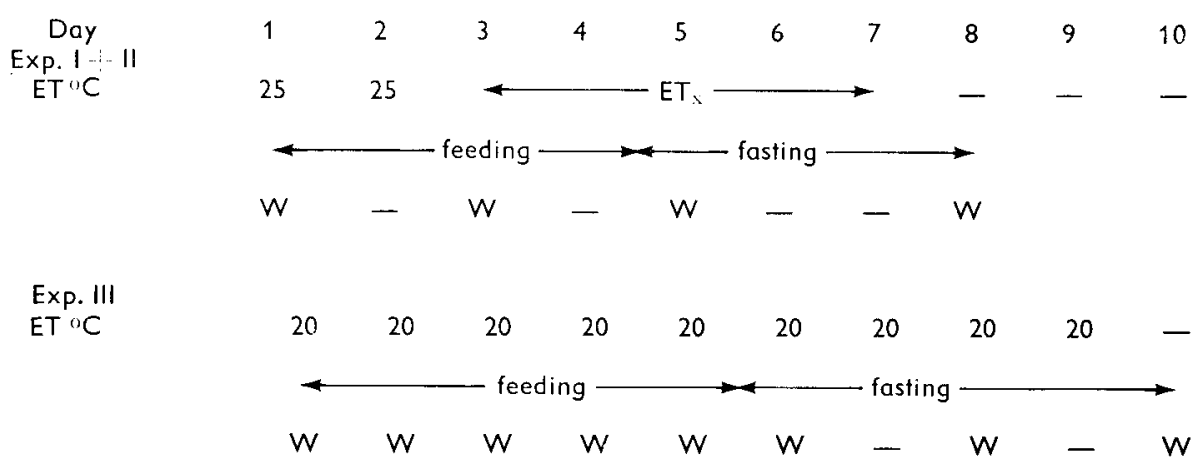

$\mathrm{ET}_{\mathrm{x}}$ : environmental temperature $\left(25,20,15,10,5^{\circ} \mathrm{C}\right)$ during a metabolic trial, the other environmental conditions being similar to those in the animal house; auditive contact was by means of an interphone.

$\mathrm{W}$ : weight $+1 \mathrm{~g}$ between $8 \mathrm{a}, \mathrm{m}$. and $10 \mathrm{a}$. m.

* Composition of growth diets : Total Crude Protein 19 p. 100, Digestible Crude Protein 17 p. 100 , Fat 2.5 p. 100, Carbohydrates 42 p. 100, Crude Fiber 4.5 p. 100, Minerals 7.5 p. 100, Dry Matter 87 p. 100, Vit A1 8,000 I. U./kg, Vit D3 1,600 I. U./kg, Vit. E $10 \mathrm{mg} / \mathrm{kg}$. Aureomycine $10 \mathrm{mg} / \mathrm{kg}$, Amprolium $125 \mathrm{mg} / \mathrm{kg}$, ethopabaat $8 \mathrm{mg} / \mathrm{kg}$.

Composition of reproductive diets : TCP 17 p. 100 , DCP 15.5 p. 100, F 3.5 p. 100 , C 42 p. 100 , CF 4.5 p. 100, M 10 p. 100, DM 87 p. 100, Vit A1 8,000 I. U. $/ \mathrm{kg}$, Vit D3 1,600 I. U. $/ \mathrm{kg}$, Vit. E. $16 \mathrm{mg} / \mathrm{kg}$. 
In a third experiment (1976-1977), 300 eggs from 1.5 to 2-year of hens of experiment 1 were incubated at $37.59 \pm 0.17 \circ \mathrm{C}$, the other conditions being the same as for experiments I and II. From 20 weeks after hatching, 36 hens were held in individual cages. The environmental temperature in the animal house was maintained constant at $20 \pm 1{ }^{\circ} \mathrm{C}$, the other environmental conditions being the same as in experiments 1 and 11 . At the age of 14 months, 7 laying animals were chosen at random to be used successively in a 9-day metabolic experiment in the same environmental conditions of temperature, humidity, convection and auditive contact (table 1).

All three experiments were carried out in an open-air circuil respiration chamber which was formerly used as an incubator (Michels ef al., 1974). $\mathrm{O}_{2}$ uptake and $\mathrm{CO}_{2}$ output were measured continuously (Geers ef al., 1978) and expressed as values per hour. Ventilation rate was calculated at standard conditions (van Es, 1961). The calculation of heat production (Romijn and Lokhorst, 1961) was adapted for kJ.

\section{Results and discussion.}

To investigate the relationships between fasting metabolism and body weight, we restricted the analysis of data to those measured during the night, when the animals were assumed to be at rest. Animals were weighed the following morning, i. e. after about 72 hrs of fasting in experiments I and II, after 48 and 96 hrs in experiment III.

First, we analysed the results from all the animals (experiments I, II, III) measured at $25^{\circ} \mathrm{C}$ and $20^{\circ} \mathrm{C}$, those temperatures being chosen in accordance with the results of Barott and Pringle $(1941,1946)$ on the thermoneutrality zone of RIR-hens.

With or without logarithmic transformation, this population taken as a whole showed no linear relationship between metabolic parameters $\left(\mathrm{CO}_{2}\right.$ production in $\mathrm{l} / \mathrm{h}, \mathrm{O}_{2}$-consumption in $\mathrm{l} / \mathrm{h}$, heat production in $\mathrm{kJ} / \mathrm{h}$ ) and body weight in fasting conditions. Indeed, a wide scattering of data was noted $(W=1.773 \pm 0.159 \mathrm{~kg}$; variation ratio $=8.97$ p. $100 ; \mathrm{Hp}=14.920 \pm 2.524 \mathrm{~kJ} / \mathrm{h}$; variation ratio $=16.9 \mathrm{p}$. $100 ; n=26$ ). Similar relationships were observed when extending the calculations to all temperatures investigated. Only the resulis of experiment II showed a linear relationship $(y=a+b x)$ (Wonnacott and Wonnacott, 1972) of heat production with body weight, the data being still widely scattered for combined measurements at $25^{\circ} \mathrm{C}$ and $20^{\circ} \mathrm{C}(\mathrm{b}=1.72 \pm 0.487 ; \mathrm{r}=0.870 ; \mathrm{n}=6 ; \mathrm{P} \leqslant 0.05)$. These last results agree with the intra-species data of Gridgeman and Heroux (1965) on rats, Mount and Rowell (1960) on pigs and Thonney ef al. (1976) in a review of the literature on different species.

To investigate the influence of the experimental group and the environmental temperature on metabolic parameters of fasting RIR hens we performed a two-way analysis of variance (Dixon, 1975) ; the results of experiments I and II were consolidated.

The significant effect of environmental temperature on $\mathrm{CO}_{2}$ production, $\mathrm{O}_{2}$ consumption and thermopoiesis was proven $(P \leqslant 0.02)$. This was further confirmed by means of simple linear regression equations (Wonnacott and Wonnacott, 1972), as illustrated for thermopoiesis in figure 1. No effects on RQ values could be observed.

We could not confirm the results of Barott and Pringle $(1941,1946)$ on thermopoiesis ; they found constant levels in RIR hens (reared in battery brooders and later 
kept in partially open laying house) within a range of environmental temperatures of about $20-25^{\circ} \mathrm{C}$. This observation possibly explains the difference between Barott and Pringle's results and ours. Indeed constant levels within a definite zone were also found in Evening Grosbeaks (Hesperiphona vespertina) reared at fluctuating temperatures, but no heat neutrality zone was observed in birds reared at constant temperafures (West and Hart, 1966). Further research on this point is recommended.

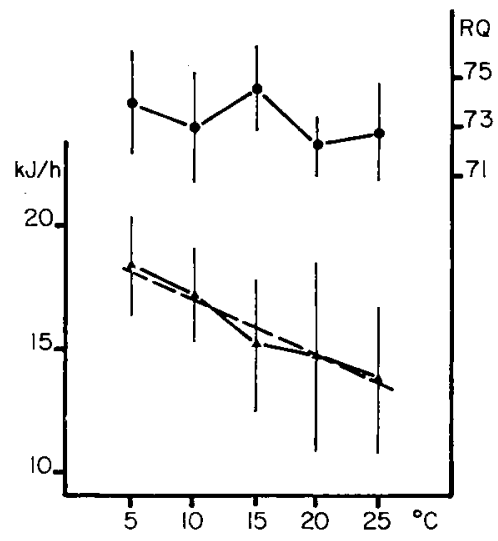

FIG. 1. - Mean values $\left( \pm s_{\bar{x}}, \mathrm{n}=6\right)$ of heat production in $\mathrm{kJ} / \mathrm{h}(\Delta)$

$(y=19.3-1.156 x ; r=-0.664, P \leqslant 0.001)$ and $R Q(\bullet)$ in relation to environmental temperatures $\left({ }^{\circ} \mathrm{C}\right)$.

To investigate other aspects of the definition and measurement of basal metabolism, we analysed the effect of prolonged fasting on metabolic parameters measured between 36-48 and 88-96 hrs of fasting in experiment III.

The results of a one-way analysis of variance (Dixon, 1975) proved the effect of duration of fasting $(P \leqslant 0.003)$. We found a descending metabolic rate expressed by negative linear relationships between the magnitude of metabolic parameters and the duration of fasting (f. e. $\mathrm{Hp}\{\mathrm{kJ} / \mathrm{h}\}=21.44-3.90$ \{duration of fasting in hours $\} \pm 1.58 ; r=-0.804 ; P \leqslant 0.01 ; n=6$ ) (Wonnacott and Wonnacott, 1972). This finding already suggests further research on metabolism during prolonged fasting.

Moreover, combining the results of experiment III and those of experiments I and II (fig. 2) measured at $25^{\circ} \mathrm{C}$ and $20^{\circ} \mathrm{C}$, we observed increasing RQ values with prolonged duration of fasting. The effects of experiment $(P \leqslant 0.0001)$ and three days of fasting $(P \leqslant 0.001)$ were statistically proved by means of an analysis of variance (Dixon, 1975). These results are in accordance with those of Dukes (1937) and Misson (1974), but not with those of Tasaki and Sakurai (1969) who report constant RQ values with fasting duration.

Our results suggest the possible influence of endogenuous and exogenuous factors and the predominance of protein metabolism during fasting, taking into account the lower level of protein $R Q$ values in birds as compared with mammals, according to Barott et al. (1938) and King (1957). These findings, indicating a probable protein metabolism during prolonged fasting, are in accordance with results of Okumura 
and Tasaki (1969) who found an increasing uric acid concentration in the blood of chickens with duration of fasting.

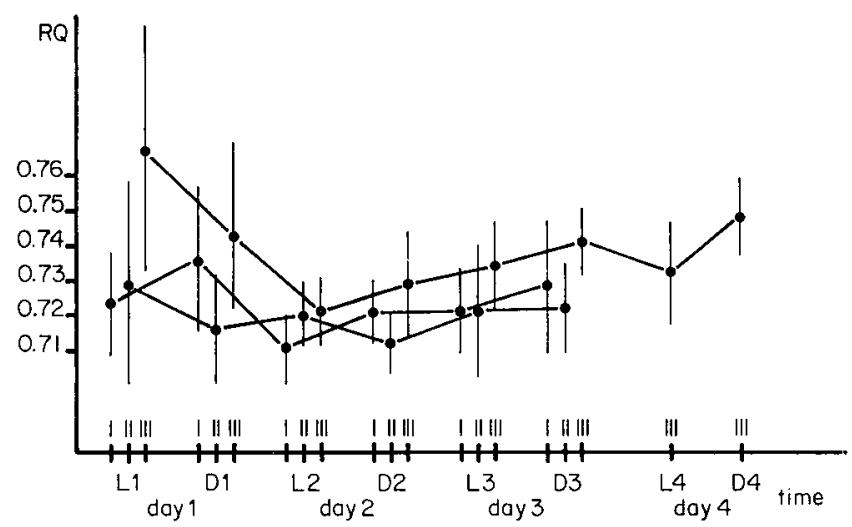

FIG. 2. - The relationship of $\mathrm{RQ}$ values $\left(\overline{\mathrm{X}} \pm s_{\bar{x}} ; \mathrm{n}=6\right)$ with the duration of fasting in comparable environments during experiments $I, I I$ and $I I I(n: 7)$.

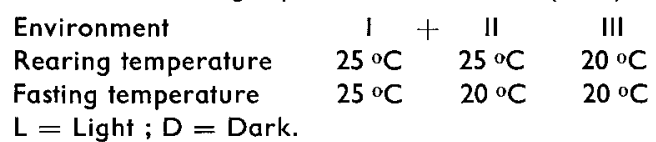

Combining all the data and using continuous registration and 1-hr measurements, we calculated $232 \mathrm{RQ}$ mean values for the light and dark subperiod. No RQ value below 0.7 was found (mean value $=0.729 ; s=0.021$; minimum $=0.700$, maximum $=0.831$ ) and this was confirmed by $1-\mathrm{hr}$ values from which the means were calculated. These results agreed with the assumption concerning respiratory katabolism in the fowl (Barott et al., 1938 ; King, 1957) and were in accordance with several authors working with other measurement methods (Dukes, 1937 ; Misson, 1974 ; Shannon et al., 1969 ; Tasaki and Sakurai, 1969 ; Waring and Brown, 1967).

\section{Conclusions.}

1. Inter-species allometric relationships between metabolic rate and body weight based on inter-species comparison were not precise enough to compare energy metabolism of fasting individuals. Since rather wide between-animal variation was present, further research is suggested on the relationship between metabolic rate and body size.

2. Relationships between fasting metabolic rate and postnatal environmental temperatures indicate further research on the range and other aspects of thermoneutrality zone in domestic fowl as well as in other birds.

3. Basal metabolic rate was more difficult to precisely define and measure due to continuous changes in metabolic rate and respiratory quotients during fasting. Stress was also a factor as noted by Heusner (1971). 
4. Results on metabolic parameters and $R Q$ values strongly suggest further systematic investigation of the effect of individual factors, i. e. especially of intermediary metabolic pathways, during fasting and feeding.

5. Within our experimental conditions and on the basis of the calculation method used no RQ values below 0.7 were found.

Reçu en ovril 1978.

Accepté en juillet 1978.

Résumé. Au cours de trois séries d'expériences sur un total de 19 poules de race Rhode Island Rouge, nous avons examiné plusieurs paramètres du métabolisme au cours d'une période de jeône, notamment les quantités d'anhydride carbonique expirées (litres par heure), d'oxygène inspirées (litres par heure) et de thermopoïèse (kJ par heure), ainsi que les niveaux des quotients respiratoires, en rapport avec le poids vif $(\mathrm{kg})$ à différentes températures.

Nous n'avons pas été en mesure de trouver des rapports interindividuels constants entre les paramètres examinés et les poids vifs des animaux soumis aux expériences.

Nous avons observé des rapports linéaires négatifs entre les valeurs des paramètres métaboliques étudiés et les températures environnantes variant entre 5 et $25^{\circ} \mathrm{C}$.

Nous avons constaté des rapports linéaires négatifs entre les niveaux des paramètres étudiés et la durée du jeûne, exprimée en nombre d'heures, à une température de $20^{\circ} \mathrm{C}$ et chez des poules en ponte ayant passé l'âge postnatal d'un an, tandis que les niveaux des quotients respiratoires augmentaient au fur et à mesure que le jeûne se prolongeait. de 0,7

Concernant le quotient respiratoire, nous n'avons pas trouvé des valeurs au-dessous

\section{References}

BAROTT H. G., FRITZ J. C., PRINGLE E. M., 1938. Heat production and gaseous metabolism of young male chickens. J. Nutr., 15, 145-167.

BAROTT H. G., PRINGLE E. M., 1941. Energy and gaseous metabolism of the hen as affected by temperature. J. Nutr., 22, 273-286.

BAROTT H. G., PRINGLE E. M., 1946. Energy and gaseous metabolism of the chicken from hatch to maturity as affected by temperature. J. Nutr., 31, 35-50.

DIXON W. J., 1975. Biomedical computer programs. Berkeley, Univ. California Press.

DUKES H. H., 1937. Studies on the energy metabolism of the hen. J. Nutr., 14, 341-354.

GEERS R., MICHELS, H., DECUYPERE E., 1978. Advances in a method for gas analysis in metabolic experiments. Ann. Biol. anim., Bioch., Biophys., 18, 1309-1315.

GRIDGEMAN N. T., HEROUX O., 1965. Relation of oxygen uptake to body weight of rats at different environmental temperatures. Can. J. Physiol. Pharmacol., 43, 351-357.

HEUSNER A. A., 1971. Criteria for standard metabolism. Env. Physiol., 15-21.

KING J. R., 1957. Comments on the theory of indirect calorimetry as applied to birds. Northwest Sci., 31, 155-169.

KLEIBER M., 1965. Metabolic body size. Proc. 3rd. Symp. Energy Metab., Troon, E. A. A. P. Publ., no 11, 427-439.

MICHELS H., GEERS R., MUAMBI S., 1974. The effect of incubation temperature on pre- and posthatching development in chickens. Br. Poult. Sci., 15, 517-523.

MISSON B. H., 1974. An open circuit respirometer for metabolic studies on the domestic fowl. Establishment of standard operating conditions. Br. Poult. Sci., 15, 287-297.

MOUNT L. E., ROWELL J. G., 1960. Body size, body temperature and age in relation to the metabolic rate of the pig in the first five weeks after birth. J. Physiol., 154, 408-416.

OKUMURA J., TASAKI I., 1969. Effect of fasting, refeeding and dietary protein level on uric acid and ammonia content of blood, liver and kidney in chickens. J. Nuir., 97, 316-320. 
ROMIJN C., LOKHORST W., 1961. Some aspects of energy metabolism in birds. Proc. 2nd. Symp. Energy Metab., Wageningen, E. A. A. P. Publ., no 10, 49-59.

SHANNON D. W. F., WARING J. J., BROWN W. O., 1969. Observations on the effect of feeding level and type of diet on the respiratory quotient of chicken with a note on the utilization of the energy of glucose, lactose, fructose and xylose. Proc. 4th Symp. Energy Metab., Warsaw, E. A. A. P. Publ, no 12, 349-360.

TASAKI I., SAKURAI H., 1969. Studies on the energy metabolism in the fowl. Mem. Lab. Anim. Nutr. Nagoya Univ., 4, 1-78.

THONNEY M. L., TOUCHBERRY R. W., GOODRICH R. D., MEISKE J. C., 1976. Intraspecies relationship befween fasting heat production and body weight : a reevaluation of $W^{0.75}$. J. Anim. Sci., 43, 692-704.

VAN ES A. J. H., 1961. Befween animal variation in the amount of energy required for the maintenance of cows. Thesis Wageningen, Pudoc.

WARING J. J., BROWN W. O., 1967. Calorimetric studies on the utilization of dietary energy by the laying White Leghorn hen in relation to plane of nutrition and environmental temperature. J. agric. Sci. Camb., 68, 140-155.

WEST G. C., HART J. S., 1966. Metabolic responses of evening grosbeaks to constant and to fluctuating temperatures. Physiol. Zool., 39, 171-184.

WONNACOTT T. H., WONNACOTT R. J., 1972. Introductary Statistics. John Wiley and Sons New-York. 